\section{UDC 631.618}

I. M. Loza ${ }^{1}$, Cand. Sc. (Biol.), orcid.org/0000-0001-7876-8624, O.Y. Pakhomov ${ }^{1}$, Dr. Sc. (Biol.), Prof., orcid.org/0000-0002-5192-6140, V. I. Chorna ${ }^{2}$, Dr. Sc. (Biol.), Prof., orcid.org/0000-0002-8815-130X, N.V. Voroshilova ${ }^{2}$, Cand. Sc. (Biol.), orcid.org/0000-0003-1434-3285
DOI: $10.29202 /$ nvngu/2018-4/16

1 - Scientific Research Institute of Biology, Oles Honchar Dnipro National University, Dnipro, Ukraine, e-mail: irinaloza23@gmail.com

2 - Dnipro State Agrarian and Economic University, Dnipro, Ukraine, e-mail: khlyzina@ukr.net

\title{
EVALUATION OF REMEDIATION EFFICIENCY OF MANGANESE QUARRY LANDS AFTER OPEN-CUT MINING: ECOSYSTEM APPROACH
}

Purpose. To assess the quality of remediated lands of Ordzhonikidzevskyi manganese quarry (Oleksandrivskyi career) on the possibility of their economic use and suitability for soil biota existence, as well as providing recommendations for further rational economic use of them.

Methodology. Assessment of quality of remediation lands was carried out by comparing remediated soil bonitet with bonitet of zonal (native) soil. Data collection and processing were carried out in terms of fill layer thickness, humus content in filling top layer, content of physical clay in topsoil and subsoil, granulometric composition of onemeter thick fill layer, topsoil and subsoil salinity (rate), composition and properties of underlying rocks.

Findings. The research revealed that as a result of implementation of technical remediation stage, a remediated soil was obtained with properties similar to zonal (native) soil previously located within this area prior to mining, and although it has less fertility and greater salinity of deeper layers, it can be used in agricultural purposes after implementation of a biological stage of remediation, which consists of salt-tolerant perennial grass cultivation for 3-5 years. The method of land remediation is currently generalized and well-studied; however, in most rehabilitation schemes on ecological recovery of industry-related areas, completeness of naturalization and functioning of remediated ecosystems is not taken into account, since most of the remediation measures are focused only on vegetation and ground macro-fauna well-being

Originality. Novelty of the work is that when assessing the remediation quality, it is proposed to take into account environmental conditions for existence of soil invertebrates, which will play a crucial role in formation of agro-system stability mechanism. These animals make a significant environmental contribution to transformation of soil features, acting as a soil protecting biological factor in organic farming.

Practical value. The performed scientific work is part of solution of modern integral ecological task on providing a human with a set of material and intangible services - natural resources and healthy environments.

Keywords: land reclamation, soil bonitet, extractive industry, ecosystem assessment, desertification

Introduction. Environment protection, rational use of natural resources and ensuring environmental safety of human life are considered to be an enabling condition for sustainable economic and social development of European countries. In this regard, solution to environmental challenges in industry-related areas of Eastern Europe is especially topical [1]. Mining activity is the most powerful effect resulting in degradation of various native landscapes. As a result of mining, agricultural lands are withdrawn from agricultural sector of economy. Instead of them, technogenic landscapes, e.g. dumps and quarries, are developed surrounded by destructive areas characterized by subsiding phenomena, rising of subsoil waters loaded with heavy metals and other contaminants, decrease in biological diversity and species richness of such sites [2]. Disturbed areas formed in the process of coal mining should be partially remediated by the way of reclamation. In Ukraine, the most common model of sulfide-containing parent rock remediation involves filling them with safety shields from loam, clay, or sand 1-1.5 m thick, with subsequent cov-

(c) Loza I. M., Pakhomov O. Y., Chorna V. I., Voroshilova N. V., 2018 ering by a layer from fertile topsoil of $0.6-0.8 \mathrm{~m}$ thick. At the initial remediation stage, landscape planning is carried out.

The main agrochemical characteristics determining agricultural productivity of reclaimed lands and suitability of them for existence of soil biota are level of actual soil acidity $(\mathrm{pH})$, salinity and particle-size composition.

Analysis of the recent research and publications. Because of intensive industrial development of Dnipropetrovsk Oblast territory, essential changes in morphology of native landscapes have been developed. For that matter, "industrial deserts" occurred instead of the native biota habitats. Desertification challenge was recognized by the international community as the biggest ecological challenge of all mankind. It is particularly relevant in arid regions of Ukraine, especially in the south region of Dnipropetrovsk Oblast. Substrates with different potential of fertility should be used in the process of miningengineering recultivation; they have different ecological properties and therefore different quality.

Soil Science Society of America defines "soil quality" term as soil capacity to functioning within an eco- 
system ensuring biological productivity, maintaining environmental quality and living conditions for animals and plants [3]. Thus, biological productivity of remediated soils is one of several aspects in determining the soil quality. The scientists note that mine spoil often has a high density, low structure, as well as the high salinity of water extracts, which together leads to extremely low suitability of such substrates for the existence of soil biota [4]. For this reason, mine spoil is overlapped with remediated layer that consists of non-toxic material (nonsaline loess-like loam, clay) in the process of reclamation. The next stage of remediation activity is covering with fertile topsoil. On the territory of steppe Ukraine, humic mass of ordinary chernozem or humusless filling substrates is applied.

The final stage of disturbed soil remediation is a biological stage. Its varieties are several ways of phytoremediation with the usage of herbaceous, arboreal and shrubby plantings [5], aimed to development of environmentally sustainable landscapes. At this stage of remediation, numerous soil-dwelling living organisms play a significant role in developing the mechanisms of ecosystems sustainability [6], especially soil mesofauna, particularly saprotrophic species such as earthworms, Enchytraeidae, millipedes, and others. As a result of their tropho-metabolic activities, these invertebrates make a significant environmental contribution to transformation of soil properties. They are called "ecosystem engineers", meaning living organisms that can influence habitats and communities of soil biota by their vital activity, and can cause ecosystem successions. It was proven enhancing efficiency of remediated soil recovery by enrichment of them with organic matter, and improving total soil [7-9].

Under modern conditions, there is a tendency to evaluate the reclamation effectiveness on the principle to maximize effect and to minimize costs considering interrelations between all elements within the ecosystem.

Unsolved aspects of the problem. Among the biota, soil mesofauna plays an important role in establishing the mechanisms for sustainability of agricultural systems; that is particularly true of saprotrophic complex such as Lumbricidae, Diplopoda species, and others. These animals due to their tropho-metabolic activities make a significant environmental contribution to transformation of soil properties, acting as soil-protective biological factors of organic farming. Possibility of soil invertebrates' existence in soil is very closely associated with environmental characteristics (soil moisture, salinity, texture, presence of litter, and others) [9]. Soil animals affect pedogenesis, fertility and structuring of soil, regulation of water regime and climate, nutrient cycle, but, despite the high ecological importance, environmental conditions for the habitat of invertebrates in the soil are hardly taken into account, especially within mining areas.

Objectives of the article. General scope of the present work was evaluation of quality of reclaimed lands of Ordzhonikidze Ore Mining and Processing Integrated Plant (OJSC), Nikopol Raion of Dnipropetrovsk
Oblast, on the possibility of their economic use and suitability for the existence of soil biota, as well as providing recommendations for further rational economic use. The subject of presented research was to assess the quality of soil reclamation with the aim to identify conditions for the existence representatives of zoocenotic block of ecosystem. Physical-chemical properties of reclaimed soil within remediated lands of the Oleksandrivskyi open quarry, OJSC made the object of the research (thickness of humic filling layer, humus content in the humic layer, content of physical clay in layer of parent rock and in humic layer, average density of layer 1 meter in thickness, salinity of topsoil and of underlying rocks (rate), composition and the properties of the underlying rocks).

Materials and Methods. The surveyed area of the Oleksandrivskyi open quarry makes about 10.0 ha. Mining plans of scale $1: 5.000$ were used as cartographic basis for the field survey. Each plot was divided into squares where pits and wells were staked angularly. There were staked 2 pits and wells; 30 samples were collected (10 in triplicate). Agrochemical analyses of soil and rock samples performed in the laboratory of SE "Dnipropetrovsk Scientific-Research and design institute of Land Management" (GOST 17.5.1.02-86. Nature Conservation...).

Brief characteristics of engineering stage of recultivation. Mining-engineering planning of the surveyed plots was carried out by PJSC "OJSC" and included the following stages:

1. The removal of a fertile layer of soil (topsoil) by bulk way, followed by storage in open heaps.

2. Reshaping and leveling of the heaps stored within a mined-out quarry space by gross way.

3. Ageing of aligned surface up to 3 years with the purpose of rock subsidence.

4. Repair of the surface affected by subsidence.

5. Covering with topsoil.

6. Ploughing of reclaimed lands.

Climate and conditions of soil moisture. District of Nikopol manganese ore basin refers to arid as for its water availability. Hydrothermal coefficient of the territory is $0.8-0.9$. The average annual rainfall is $401 \mathrm{~mm}$. Tenday mean rainfall is $7-20 \mathrm{~mm}$, while the maximum is observed in June-July $(17-20 \mathrm{~mm})$. Average annual temperature is $+8.8{ }^{\circ} \mathrm{C}$. Duration of effective temperatures is above $+5^{\circ} \mathrm{C}$ is 214 days; accumulated temperatures are $3487^{\circ}$. Duration of temperatures over $+10^{\circ} \mathrm{C}$ is 178 days; accumulated temperatures are $3216^{\circ} \mathrm{C}$. Temperature regimen is characterized by wide temperature gradients, which leads to intense rock weathering of reclaimed lands and the release of mineral nutrients. Continued rainless periods with relative humidity up to $30 \%$ and strong dry winds determine unfavorable climatic effects. Moisture of remediated soil occurs only through rainfalls. The surveyed area of the Oleksandrivskyi open quarry reclaimed lands located within territory of the Pokrovska Rural Soviet; it covers an area of 10.0 hectares and is intended for use in arable farming. The territory belongs to the Apostolivskyi natural-agricultural district, province of the desert steppe on the Dnipro 
right bank. The surface slope of the surveyed area does not exceed $1^{\circ}$. Microdepressions and other kinds of surface deformations from subsidence have not been observed. The surveyed area of reclamation is represented by one whole plot.

Characteristics of evaluation units. Soil bonitet is a comparative evaluation of soil fertility, which determines the rate of soil suitability for crop cultivation. Soil suitability group was adopted as an evaluation soil unit in assessment of native soil. Regarding reclaimed soils, it is not possible to allocate such evaluation groups and to compile a uniform list, since the parameters of actual remediation do not always correspond to the design parameters. According to design data, remediated lands should be covered with humic layer $50 \mathrm{~cm}$ thick; as subsoil should be used nonsaline loesslike loam to a depth of $150 \mathrm{~cm}$.

Data collection on properties of reclaimed lands is carried out per plots of completed reclamation. These data were obtained from the materials of soil agrochemical studies. The texture of remediated soil of the Oleksandrivskyi open quarry was described as a mixture of bulk humic layer and underlying rocks. Soil investigation was carried out by a series of soil profiles. Collection and processing of data were carried out on the following parameters: 1) thickness of the humic layer, $\mathrm{cm} ; 2$ ) humus content in the humic layer, \%; 3 ) content of physical clay in the humic layer and underlying rock, \%; 4) particle-size distribution in the bulk layer 1 meter thick; 5) salinity of the topsoil and subsoil (rate); 6) composition and properties of the underlying rocks.

Humus content was determined according to DSTU 4289:2004 "Soil Quality. Methods for Determining Soil Organic Matter". Analysis of the water soil extract was carried out according to GOST 26425-85 "Soil. Methods for determination of chloride ion in water extract", GOST 26426-85 "Soils. Methods for determination of sulphate ion in water extract", GOST 26427-85 "Soils. Method for determination of sodium and potassium in water extract", GOST 26428-85 "Soil. Methods for determination of calcium and magnesium in water extract". Particle-size distribution of the bulk soil layer was determined according to GOST 12536-79 "Soils. Laboratory determination of particle-size distribution".

With the purpose of bonitation, a numerical scale of 100 points is applied, and soil quality by bonitet is assessed in points from $81-100$ (very fertile) up to 20 and less (the least fertile). To account for pedogenesis processes that significantly affect the yield but are not identified with the use of quantitative indicators, the correction coefficients specific for areas are applied. To calculate the bonitet scores of reclaimed lands at the initial stages of usage, the first three fertility indicators are used as correction factors. The bonitet scores calculated are compared with those of reference zonal soil and conclusions are made as for the value of a given soil with the position of agricultural use, and in economic calculations of land monetary evaluation.

Presentation of the main research and scientific results. Characteristics of reclaimed soil. The underlying rocks. Kinds of rocks that underlie the fertile soil layer within the study area are Pleistocene loess deposits (up to 3 tiers), red-brown Pleiocen clay and man-made mixture of the above rocks. Man-made mixtures from loess deposits, red-brown clays and grey-green clays predominate in composition of the underlying rocks within the studied territory. The basis of clay fraction is silt whose content varies from 28.7 to $45.0 \%$. The content of easily soluble salts varies from 0.350 to $0.620 \%$ (dry residue). Loess rocks are slightly and medium saline. Salinity types are sulfate and chloride-sulfate.

As a result of soil survey, moderately clayey southern chernozem and fine-textured low-humic ordinary chernozem soil had previously been placed in site of the Oleksandrivskyi open quarry. As a reference for bonitation of re-cultivated land used for arable farmland, ordinary chernozem soil, fine-textured, low-humic, shallow was used in this region. This soil is characterized by the following main parameters: thickness of humic horizons $(\mathrm{H}+\mathrm{Hp})$ of $54 \mathrm{~cm}$; humus content in the topsoil of $3.5 \%$; content of physical clay in the topsoil of $54.8 \%$. A score of bonitet is 84 , considering the environmental factor that amounted 41. Above data are necessary in assessment of reclaimed lands. The presented soil is wellenriched with nitrogen and phosphorus, and it contains the abundance of potassium; the soil has a neutral reaction of soil solution. Carbonates are accumulated at a depth of 35-45 cm, and with no salinity. Loess and loesslike loams are subsoil rocks. Thus, fine-textured low-humic ordinary chernozem soils are the most valuable lands of multi-purpose within the surveyed region. Evaluation of land reclamation effectiveness is an integral part of soil and agrochemical survey, and it includes bonitation of recultivated soils.

Topsoil quality. During selective removal of humic layer on the zonal soil which is further used for reclamation, it is mixed (diluted) with humusless loam, resulting in depletion of the fertile soil layer in chemical elements and compounds necessary for plant growth, especially in available nitrogen; as a result, the soil becomes more calcareous, and it contains $1.6-2.0 \%$ of humus, that is by $1.5-2$ times less than that in topsoil of native soil. The filled layer of southern chernozem is presented by a mixture of topsoil with subsoil. It has grayish-brown colour, sometimes spotted, caused by inclusions of pale yellow loesslike loam. Humus content in the layer of $0-10 \mathrm{~cm}$ was varied from 2.1 to $2.3 \%$ with the average of $2.2 \%$. The humic layer varied in thickness from 56 to $67 \mathrm{~cm}$. Average depth of filled topsoil was $62 \mathrm{~cm}$. Salinization with water-soluble salts above the toxicity threshold in topsoil of the studied soil was not identified. The soil is compacted below the plow pan. Calcium carbonates are observed throughout the soil profile.

Underlying rocks. Underlying rocks do not differ by diversity and are represented by a man-made mixture of loesslike loam and red-brown clays. Underlying rocks of the Oleksandrivskyi open quarry (according to chemical analyses data) contain water-soluble salts above toxicity threshold at a depth of $30-100 \mathrm{~cm}$. The underlying rocks are slightly and middle-salinized at sulfate type.

Determination of the underlying rocks effect on the productivity of reclaimed lands. Long-term studies of re- 
claimed lands within the OJSC, Ordzhonikidze, conducted by Dnipropetrovsk Agricultural Institute, revealed the negative impact of saline rocks on the reclaimed lands productivity. As for the Oleksandrivskyi open quarry, the influence coefficient was equal to 0.76 .

Mechanical composition of soil. Analyzing the data represented, the following should be noted:

1. Mechanical composition of the filled humic layer (soil layer 0-30 cm deep) of the surveyed area was middle-loamy. Mechanical composition of the layer 30$100 \mathrm{~cm}$ in depth was fine-textured. On average, content of physical clay in the career in the layer of $0-30 \mathrm{~cm}$ was $42.9 \%$; in the layer of $30-100 \mathrm{~cm}$ it was $46.3 \%$; in the layer of $0-100 \mathrm{~cm}$ it was $45.3 \%$ (Table 1 ).

Salinity of reclaimed soil. Analysis of water extracts of recultivated soils of the Oleksandrivskyi open quarry revealed the presence of water-soluble salts above the toxicity threshold in the underlying rocks.According to the type of salinity, the reclaimed soil is weakly-salinized solonchak-like soil on the area of 6.1 ha (salinized at depth 30$80 \mathrm{~cm}$ ) and middle-salinized solonchak-like soil on the area of 3.9 ha. Salinity type is sulphatic (Table 2).

Assessment of remediated soil. Bonitation of reclaimed lands on the agri-environmental basis is implemented with the use of soil-ecological indexes. This approach provides an opportunity to consider practically the entire complex of abiotic and biotic factors in the system of man-made edaphotop. According to N. Bekarevich, the performance of remediated edaphotops is determined by several factors such as the content of humus and nutrients, thickness of humic layer, the physical properties of underlying rock in $1 \mathrm{~m}$ layer, content of water-soluble salts and carbonates, and others. Studies have established that the productivity of reclaimed soil in the process of its usage does not reach performance level of the native soil. To determine score of bonitet of remediated soil the following characteristics of its properties were used (average on the plot, Table 3).
As a result of remediation conducted, artificial soil was obtained characterized by the following main parameters: depth of humus horizons $(\mathrm{H}+\mathrm{HP}) 62 \mathrm{~cm}$; humus content in the topsoil $2.2 \%$; content of physical clay in the topsoil $45.3 \%$. A score of bonitet was 62 , considering the environmental factor 30 , while a score of native soil bonitet amounted 41 (Table 4).

Thus, the investigation has demonstrated that reclamation works on the territory of OJSC mining (on the example of the Oleksandrivskyi open quarry) were carried out at the proper level. As a result of mining operations, topsoil of recultivated soil is depleted in chemical elements which are necessary for plant growth; as a result, the soil becomes more calcareous, and contains humus by 1.5-2 times less than that in topsoil of undisturbed soil. Topsoil thickness is on average $62 \mathrm{~cm}$. Humus content in the filled layer on average is $2.2 \%$. Mechanical composition of the arable layer is middle loamy. The soil is compacted below the plow pan. Mechanical composition of the underlying rock is fine-textured. Salinization with water-soluble salts above the toxicity threshold in topsoil of the studied soil has not been identified. Analysis of water extracts of underlying rocks revealed the presence of water-soluble compounds above the toxicity threshold. According to the type of salinity, reclaimed soil is weakly-salinized, solonchaklike soil on the area of 6.1 ha and middle-salinized solonchak-like soil on the area of 3.9 ha. Salinity type is sulfate. Calcium carbonates are observed throughout the soil profile.

Summary. Thus, as a result of technical stage of reclamation artificial reclaimed soil was made with features similar to those of native zonal soil located in this area prior to mining operations, and, although it has slightly lower fertility and greater salinity of the lower horizons, it can be used successfully in agricultural purposes. Correction coefficients for underlying and salinity do not significantly change the results of the soil evaluation,

Table 1

Mechanical composition analysis of the reclaimed soils in the Oleksandrivskyi open quarry, OJSC

\begin{tabular}{|c|c|c|c|c|c|c|c|c|c|c|c|}
\hline \multirow[b]{2}{*}{$\begin{array}{l}\overline{0} \\
\dot{0} 0 \\
40 \\
\dot{0} 0 \\
\dot{0} \\
\dot{0}\end{array}$} & \multirow[b]{2}{*}{$\begin{array}{l}\text { Index of } \\
\text { horizons }\end{array}$} & \multirow[b]{2}{*}{$\begin{array}{c}\text { Sample } \\
\text { collection depth, } \\
\mathrm{cm}\end{array}$} & \multirow[b]{2}{*}{$\begin{array}{l}\text { Hygroscopic } \\
\text { water, \% }\end{array}$} & \multirow[b]{2}{*}{$\begin{array}{l}\text { Humus } \\
\text { content, \% }\end{array}$} & \multicolumn{7}{|c|}{ Mechanical composition, $\%$ of particle with diameter, $\mathrm{mm}$} \\
\hline & & & & & $\begin{array}{c}\text { more } \\
\text { than } 0.25\end{array}$ & $\begin{array}{l}2 \\
0 \\
0 \\
1 \\
\\
0\end{array}$ & $\begin{array}{l}0 \\
\vdots \\
1 \\
1 \\
0 \\
0\end{array}$ & $\begin{array}{l}n \\
0 \\
0 \\
0 \\
1 \\
0 \\
0\end{array}$ & $\begin{array}{l}\overrightarrow{8} \\
0 \\
0 \\
2 \\
8 \\
0\end{array}$ & $\begin{array}{c}\text { less than } \\
0.001\end{array}$ & $\begin{array}{c}\text { less than } \\
0.01\end{array}$ \\
\hline \multirow[t]{5}{*}{1} & $\mathrm{H}+\mathrm{Hp}+\mathrm{Ph}$ & $0-10$ & 3.6 & 2.1 & 0.7 & 2.6 & 53.8 & 8.2 & 8.3 & 26.4 & 42.9 \\
\hline & $\mathrm{H}+\mathrm{Hp}+\mathrm{Ph}$ & $20-30$ & 3.5 & 1.8 & - & - & - & - & - & - & - \\
\hline & $\mathrm{H}+\mathrm{Hp}+\mathrm{Ph}$ & $40-50$ & 3.5 & 1.5 & 0.3 & 3.2 & 52.6 & 7.0 & 8.1 & 28.8 & 43.9 \\
\hline & $\mathrm{H}+\mathrm{Hp}+\mathrm{Ph}$ & $58-67$ & 4.0 & 1.0 & - & - & - & - & - & - & - \\
\hline & $\mathrm{Pk}$ & $90-100$ & 3.5 & - & 3.3 & 18.6 & 29.4 & 7.7 & 7.1 & 33.9 & 48.7 \\
\hline \multirow[t]{5}{*}{2} & $\mathrm{H}+\mathrm{Hp}+\mathrm{Ph}$ & $0-10$ & 3.8 & 2.3 & 0.4 & 0 & 53.1 & 11.6 & 7.9 & 27.0 & 46.5 \\
\hline & $\mathrm{H}+\mathrm{Hp}+\mathrm{Ph}$ & $20-30$ & 3.8 & 2.3 & - & - & - & - & - & - & - \\
\hline & $\mathrm{H}+\mathrm{Hp}+\mathrm{Ph}$ & $40-50$ & 3.8 & 1.5 & 4.9 & 12.3 & 38.1 & 6.0 & 7.2 & 31.5 & 44.7 \\
\hline & $\mathrm{H}+\mathrm{Hp}+\mathrm{Ph}$ & $48-56$ & 4.3 & 1.3 & - & - & - & - & - & - & - \\
\hline & $\mathrm{Pk}$ & $90-100$ & 4.2 & - & 6.6 & 22.2 & 25.5 & 4.0 & 7.6 & 34.1 & 45.7 \\
\hline
\end{tabular}


Analysis of water-soluble compounds of the reclaimed soils in the Oleksandrivskyi open quarry, OJSC

\begin{tabular}{|c|c|c|c|c|c|c|c|c|c|c|c|}
\hline \multirow{2}{*}{ 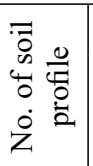 } & \multirow[b]{2}{*}{$\begin{array}{l}\text { Index of } \\
\text { horizons }\end{array}$} & \multirow{2}{*}{$\begin{array}{c}\text { Sample } \\
\text { collection } \\
\text { depth, cm }\end{array}$} & \multicolumn{9}{|c|}{ Water extraction, $\%$ mg-eq per $100 \mathrm{~g}$ of soil } \\
\hline & & & $\begin{array}{c}\text { dry residue, } \\
\%\end{array}$ & $\mathrm{CO}_{3}^{2-}$ & $\mathrm{HCO}_{3}^{-}$ & $\mathrm{Cl}^{-}$ & $\mathrm{SO}_{4}^{2-}$ & $\mathrm{Ca}^{2+}$ & $\mathrm{Mg}^{2+}$ & $\mathrm{Na}^{+}$ & $\begin{array}{c}\mathrm{pH} \text { of water } \\
\text { extract }\end{array}$ \\
\hline \multirow[t]{5}{*}{1} & $\mathrm{H}+\mathrm{Hp}+\mathrm{Ph}$ & $0-10$ & 0.106 & - & 0.83 & 0.29 & 0.40 & 0.73 & 0.73 & 0.06 & 6.78 \\
\hline & $\mathrm{H}+\mathrm{Hp}+\mathrm{Ph}$ & $20-30$ & 0.078 & - & 0.56 & 0.15 & 0.54 & 0.73 & 0 & 0.52 & 6.56 \\
\hline & $\mathrm{H}+\mathrm{Hp}+\mathrm{Ph}$ & $40-50$ & 0.106 & - & 0.74 & 0.29 & 0.50 & 0.62 & 0.82 & 0.09 & 7.02 \\
\hline & $\mathrm{H}+\mathrm{Hp}+\mathrm{Ph}$ & $58-67$ & 0.404 & - & 0.56 & 0.73 & 4.75 & 2.50 & 2.08 & 1.46 & 7.16 \\
\hline & $\mathrm{Pk}$ & $90-100$ & 0.387 & - & 0.56 & 0.80 & 4.31 & 2.06 & 3.09 & 0.52 & 7.98 \\
\hline \multirow[t]{5}{*}{2} & $\mathrm{H}+\mathrm{Hp}+\mathrm{Ph}$ & $0-10$ & 0.087 & - & 0.62 & 0.11 & 0.40 & 0.62 & 0.21 & 0.30 & 6.82 \\
\hline & $\mathrm{H}+\mathrm{Hp}+\mathrm{Ph}$ & $20-30$ & 0.104 & - & 0.74 & 0.32 & 0.50 & 0.73 & 0.83 & 0 & 7.12 \\
\hline & $\mathrm{H}+\mathrm{Hp}+\mathrm{Ph}$ & $40-50$ & 0.281 & - & 0.60 & 0.55 & 3.21 & 1.98 & 1.14 & 1.24 & 7.54 \\
\hline & $\mathrm{H}+\mathrm{Hp}+\mathrm{Ph}$ & $48-56$ & 0.526 & - & 0.56 & 0.94 & 6.20 & 2.29 & 2.18 & 3.23 & 7.56 \\
\hline & $\mathrm{Pk}$ & $90-100$ & 0.620 & - & 0.50 & 0.89 & 7.77 & 2.60 & 2.60 & 3.96 & 8.12 \\
\hline
\end{tabular}

Table 3 tions favourable to the existence of soil invertebrates. It

Characteristics of reclaimed soil

\begin{tabular}{|l|c|}
\hline \multicolumn{1}{|c|}{ Parameter } & $\begin{array}{c}\text { Parameter } \\
\text { value }\end{array}$ \\
\hline Humus layer thickness, cm & 62 \\
\hline Humus content in the layer of $0-10 \mathrm{~cm}, \%$ & 2.2 \\
\hline $\begin{array}{l}\text { Content of physical clay in the layer of } 0 \text { - } \\
100 \mathrm{~cm}, \%\end{array}$ & 45.3 \\
\hline Correction factors for: & \\
\hline - underlying rocks & 0.90 \\
\hline - salinization & 0.76 \\
\hline
\end{tabular}

which indicates similarity of its main physical and chemical characteristics to the native zonal chernozem. The results of experiments show that in the future artificial reclaimed soil in the territory of the Oleksandrivskyi open quarry (OJSC) will form environmental condi- is possible to predict that after the biological step of remediation, which is the sowing of the remediated soils with ecologically tolerant perennial grasses, environmental properties of the soil will further improve and conditions optimal for the existence of invertebrate animal communities will develop similar to those of native zonal soil; it will lead to further soil naturalization, increasing its environmental sustainability and productivity.

Recommendations for improvement of reclaimed soil. Before agricultural use of reclaimed lands, it is essential to repair reclaimed lands (if necessary) and biological reclamation (required). At the biological stage, agro-physical (structure, porosity, air conditions, water permeability), agrochemical (enrichment in humus and nutrients), and chemical (removal from easily soluble salts) soil properties are improved. This is achieved through cultivation of salt-resistant perennial grasses for $3-5$ years. For this, grass mixtures are recommended with the following seeding rate, in $\mathrm{kg}$ per 1 ha:

Table 4

Calculations of bonitet points on the properties of recultivated soils of the Oleksandrivskyi open quarry, OJSC

\begin{tabular}{|c|c|c|c|c|c|c|c|c|c|c|c|c|c|c|}
\hline \multirow[b]{3}{*}{ Name of soil } & \multicolumn{9}{|c|}{ Properties of soil and its assessment, in scores } & \multirow{3}{*}{ 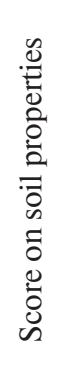 } & \multirow{2}{*}{\multicolumn{2}{|c|}{$\begin{array}{l}\text { Correction } \\
\text { factors for }\end{array}$}} & \multirow{2}{*}{\multicolumn{2}{|c|}{ Final score }} \\
\hline & \multicolumn{3}{|c|}{$\begin{array}{l}\text { depth } \\
\text { of humic } \\
\text { horizons }\end{array}$} & \multicolumn{3}{|c|}{$\begin{array}{l}\text { humus } \\
\text { content in } \\
\text { the topsoil }\end{array}$} & \multicolumn{3}{|c|}{$\begin{array}{l}\text { content of } \\
\text { physical clay }\end{array}$} & & & & & \\
\hline & 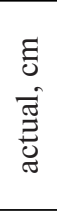 & 范 & 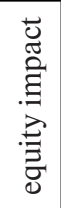 & 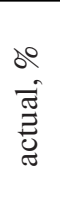 & : & 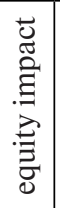 & 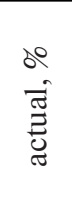 & 苛 & 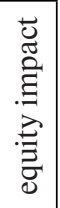 & & 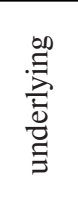 & 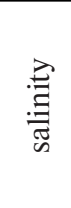 & $\begin{array}{l}\text { without } \\
\text { environmental } \\
\text { coefficient }\end{array}$ & $\begin{array}{l}\text { with } \\
\text { environmental } \\
\text { coefficient of } \\
0.49\end{array}$ \\
\hline $\begin{array}{l}\text { Ordinary chernozem, } \\
\text { fine-textured, low-humic, } \\
\text { shallow }\end{array}$ & 54 & - & - & 3.5 & - & - & 54.8 & - & - & - & - & - & 84 & 41 \\
\hline $\begin{array}{l}\text { Reclaimed soils (average } \\
\text { on site) }\end{array}$ & 62 & 114 & 95 & 2.2 & 63 & 47 & 45.3 & 94 & 53 & 91 & 0.90 & 0.76 & 62 & 30 \\
\hline
\end{tabular}


1. Yellow alfalfa (Medicago falcata L.) $-6-8+$ Awnless bromegrass (Bromus inermis L.) $-10-12+$ Couch grass (Elytrigia repens L.) $-8-10$.

2. Awnless bromegrass (Bromus inermis L.) $-25+$ + Alfalfa blue-hybrid (Medicago varia Mart.) - 18 .

3 . Technologies of work on the biological reclamation should be developed in a separate work project.

Acknowledgments. The present work was carried out in the Institute of Biology, Oles Honchar Dnipro National University. The study materials are part of the research in the framework of the state budget of the Ministry of Education and Science of Ukraine: d/b No. 1-32517 "Ecological basis of zoopertinent impact of animals on processes of native and disturbed ecosystems optimization in the context of modern environmental management", d/b No. 1-290-15 "Zoogenic mechanisms of ecosystem services and development of ecological principles for its conservation and restoration", as well as contract work with the State enterprise "Dnipropetrovsk Scientific-research and Design Institute of Land Management". The authors express their appreciation to the engineers Nazimov S. S., Neklesa A. O., leading specialist Mishchenko L. V. for the assistance and cooperation in the research work.

\section{Reference.}

1. Pecharová, E., Martis, M., Kašparová, I. and Zdražil, V., 2011. Environmental approach to methods of regeneration of disturbed landscapes. Journal of Landscape Studies [pdf], 4, pp. 71-80. Available at: <http:// www.centrumprokrajinu.cz/files/JLS_Volume\%204_ pp\%2071-80.pdf> [Accessed 20 September 2017].

2. Kulbachko, Y., Loza, I., Pakhomov, O. and Didur, O., 2011. The zoological remediation of technogen faulted soil in the industrial region of the Ukraine Steppe zone. In: M. Behnassi, ed., Sustainable Agricultural Development, Springer Science+Business Media: Springer Dordrecht Heidelberg London New York. pp. 115-123. Available at: <https://www.springerprofessional.de/the-zooecological-remediation-of-technogen-faulted-soil-in-the-i/4733268> [Accessed 22 October 2017].

3. Karaca, A., 2011. Biology of Earthworms, Soil Biology 24, Springer-Verlag Berlin Heidelberg. DOI: 10.1007/ 978-3-642-14636-7 16.

4. Kulbachko, Y. L., Didur, O. A., Loza, I. M. and Kryuchkova, A. I., 2016. Effects of saprophages (Earthworms, Lumbricidae, and Millipedes, Diplopoda) on ecosystem services implementation: optimization of some ecological functions in remediated soil. In: O. Y. Pakhomov, ed., Issues of the ecosystem services provided by animals under anthropogenic pressure within Ukrainian steppe. Vienna: "East West" Association for Advanced Studies and Higher Education GmbH., Ch. 4, pp. 62-87.

5. Lovinska, V., Sytnyk, S., Kharytonov, M. and Loza, I., 2016. Features of pine stands function in Dnieper North Steppe, Ukraine. The Journal "Agriculture and Forestry", 62(1), pp. 155-163. DOI: 10.17707/ AgricultForest.62.1.18.

6. Maltseva, I.A. and Baranova, O.A., 2014. Algae of technogen ecotopes of iron-ore plant. Algology, 24(3), pp. 350-353. Available at: <http://nbuv.gov.ua/UJRN/ algol_2014_24_3_25> [Accessed 20 October 2017].

7. Pakhomov, O. Y. and Shulman, M. V., 2017. Features of Birds Corpses Decomposition and Utilization Processes in Different Forest Biogeoecoenosis in Steppe Dnipro River Area. Ornithological reading of memory M. A. Voinstvensky (collection of works). Vestnik zoologii, Journal of Schmalhausen Institute of Zoology, 35, 1-88, pp. 59-61.

8. Shulman, M. V., Pakhomov, O.Y. and Brygadyrenko, V. V., 2017. Effect of lead and cadmium ions upon the pupariation and morphological changes in Calliphora vicina (Diptera, Calliphoridae). Folia Oecologica, 44(1), pp. 28-37. DOI: 10.1515/foecol-2017-0004.

9. Brygadyrenko, V. V., 2016. Influence of litter thickness on the structure of litter macrofauna of deciduous forests of Ukraine's steppe zone. Visnik Dnipropetovsk University. Series Biology, Ecology, 24(1), pp. 240-248. DOI: $10.15421 / 011630$.

\section{Оцінка ефективності рекультивації земель кар'єра видобутку марганцевої руди: екосистемний підхід}

\section{I. М. Лоза ${ }^{1}$, О. С. Пахомов ${ }^{1}$, В. І. Чорна ${ }^{2}$, Н. В. Ворошилова ${ }^{2}$}

1 - Науково-дослідний інститут біології Дніпровського національного університету імені О. Гончара, м. Дніпро, Україна, e-mail: irinaloza23@gmail.com

2 - Дніпровський державний аграрний університет, м. Дніпро, Україна, e-mail: khlyzina@ukr.net

Мета. Оцінка якості рекультивованих земель Орджонікідзевського гірничо-збагачувального комбінату на прикладі Олександрівського кар'єру на можливість їх господарського використання та придатності для існування грунтової біоти, а також надання рекомендацій щодо подальшого раціонального господарського використання.

Методика. Оцінку якості рекультивації проводили шляхом порівняння бонітету рекультивованих грунтів із бонітетом зональних грунтів. Збір i обробку даних проведено за показниками потужності насипного шару, вмісту гумусу в насипному шарі, вмісту фізичної глини в насипному шарі та в підстилаючій породі, гранулометричного складу насипного шару метрової товщини, ступеня засолення насипного родючого шару й підстилаючих порід (ступінь), складу та властивості підстилаючих порід.

Результати. Дослідженнями було встановлено, що в результаті виконання технічного етапу рекультивації було одержано рекультивований грунт, який за характеристиками є схожим із природними зональними грунтами, розташованими раніше на цій ділянці до проведення гірничих робіт, i, хоча він має меншу родючість і більшу засоленість нижніх горизонтів, його можна використовувати для господарських цілей після проведення біологічного етапу рекультивації, що полягає у вирощуванні солетривких багаторічних трав протягом $3-5$ років. 
Методика рекультивації земель на теперішній час узагальнена й добре вивчена, однак у більшості рекультиваційних схем екологічного відновлення техногенних територій не врахована повнота натуралізації та функціонування рекультивованих екосистем, оскільки більшість рекультиваційних заходів зосереджено лише на стані рослинності й наземної макрофауни.

Наукова новизна. Полягає в тому, що при оцінці якості рекультивації запропоновано враховувати екологічні умови для існування грунтових безхребетних, що відіграють важливу роль у створенні механізмів стійкості агросистем. Ці тварини вносять значний екологічний внесок у перетворення грунтових властивостей, виступаючи як грунтозахисний біологічний фактор органічного землеробства.

Практична значимість. Виконана наукова робота є складовою частиною рішення інтегральної сучасної екологічної задачі щодо забезпечення людини сукупністю матеріальних і нематеріальних благ природними ресурсами та здоровим довкіллям.

Ключові слова: рекультивація земель, бонітування грунтів, видобувна промисловість, екосистемна оцінка, спустелювання

\section{Оценка эффективности рекультивации земель карьера добычи марганцевой руды: экосистемный подход}

\author{
И. М. Лоза ${ }^{1}$, А. Е. Пахомов ${ }^{1}$, В. И. Черная ${ }^{2}$, \\ Н. В. Ворошилова ${ }^{2}$
}

1 - Научно-исследовательский институт биологии Днепровского национального университета имени О. Гончаpa, г. Днепр, Украина, e-mail: irinaloza23@gmail.com 2 - Днепровский государственный аграрно-экономический университет, г. Днепр, Украина, e-mail: khlyzina@ ukr.net

Цель. Оценка качества рекультивированных земель Орджоникидзевского горно-обогатительного комбината на примере Александровского карьера относительно возможности их хозяйственного использования и пригодности для существования почвенной биоты, а также предоставление рекомендаций по дальнейшему рациональному хозяйственному использованию.

Методика. Оценку качества рекультивации проводили путем сравнения бонитета рекультивированных почв с бонитетом зональных почв. Сбор и обработку данных проводили по показателям мощ- ности насыпного слоя, содержания гумуса в насыпном слое, содержания физической глины в насыпном слое и в подстилающей породе, гранулометрического состава насыпного слоя метровой толщины, степени засоления насыпного плодородного слоя и подстилающих пород (степень), состава и свойств подстилающих пород.

Результаты. Исследованиями было установлено, что в результате выполнения технического этапа рекультивации была получена рекультивированная почва, по характеристикам аналогичная природным зональным почвам, ранее расположенным на этом участке до проведения горных работ, и, хотя она обладает меньшим плодородием и более высокой засоленностью нижних горизонтов, такую почву можно использовать для хозяйственных целей после проведения биологического этапа рекультивации, который заключается в выращивании солестойких многолетних трав в течение 35 лет. Методика рекультивации земель в настоящее время достаточно хорошо изучена, однако в большинстве рекультивационных схем экологического восстановления техногенных территорий не учтена полнота натурализации и функционирования рекультивированных экосистем, поскольку большинство рекультивационных мероприятий сосредоточены только на состоянии растительности и наземной макрофауны.

Научная новизна. Заключается в том, что при оценке качества рекультивации предложено учитывать экологические условия для существования почвенных беспозвоночных, которые играют важную роль в создании механизмов устойчивости агросистем. Эти животные вносят значительный экологический вклад в преобразование почвенных свойств, выступая в качестве почвозащитного биологического фактора органического земледелия.

Практическая значимость. Выполненная научная работа является составной частью решения интегральной современной экологической задачи по обеспечению человека совокупностью материальных и нематериальных благ - природными ресурсами и здоровой окружающей средой.

Ключевые слова: рекультивация земель, бонитировки почв, добывающая промышленность, экосистемная оценка, опустынивание

Рекомендовано до публікації докт. біол. наук В.М. Звєрковським. Дата надходження рукопису 17.07.17. 